Cornell University Law School Scholarship@Cornell Law: A Digital Repository

$11-2004$

\title{
Appeal Rates and Outcomes in Tried and Nontried Cases: Further Exploration of Anti-Plaintiff Appellate Outcomes
}

Theodore Eisenberg

Cornell Law School, ted-eisenberg@lawschool.cornell.edu

Follow this and additional works at: http://scholarship.law.cornell.edu/facpub

Part of the Applied Statistics Commons, Civil Procedure Commons, and the Litigation Commons

\section{Recommended Citation}

Eisenberg, Theodore, "Appeal Rates and Outcomes in Tried and Nontried Cases: Further Exploration of Anti-Plaintiff Appellate Outcomes" (2004). Cornell Law Faculty Publications. Paper 359.

http://scholarship.law.cornell.edu/facpub/359 


\title{
Appeal Rates and Outcomes in Tried and Nontried Cases: Further Exploration of Anti-Plaintiff Appellate Outcomes
}

\author{
Theodore Eisenberg*
}

Federal data sets covering district court and appellate court civil cases for cases terminating in fiscal years 1988 through 2000 are analyzed. Appeals are filed in 10.9 percent of filed cases, and 21.0 percent of cases if one limits the sample to cases with a definitive judgment for plaintiff or defendant. The appeal rate is 39.6 percent in tried cases compared to 10.0 percent of nontried cases. For cases with definitive judgments, the appeal filing rate is 19.0 percent in nontried cases and 40.9 percent in tried cases. Tried cases with definitive judgments are appealed to a conclusion on the merits in 22.7 percent of concluded trials compared to 10.2 percent of concluded nontried cases. Appellate courts affirm and reverse at different rates appeals from judgments for plaintiffs and defendants. Defendants achieve reversal of adverse trial court judgments in about 10 percent of filed cases and suffer affirmance in about 15 percent of such cases. Plaintiffs achieve reversal in about 4 percent of adverse trial court judgments and suffer affirmance in about 16 percent of such cases. Asymmetrical reversal rates are shown to be in part possibly attributable to different trial-win rates. But the data suggest that an appellate court effect exists, independent of trial-win rates and appeal rates, that depresses plaintiff success on appeal in employment discrimination cases.

Little is known about the frequency or rate of appeals from trials or nontrials, their treatment on appeal, or tried cases' relative fraction of the appellate docket. Earlier work explores the relation of plaintiff-defendant status and appellate court outcomes, ${ }^{1}$

(C2004 American Bar Association. All rights reserved.

*Henry Allen Mark Professor of Law, Cornell Law School, Myron Taylor Hall, Ithaca, NY 14853; e-mail theodore-eisenberg@postoffice.law.cornell.edu; Bruce W. Nichols Visiting Professor of Law, Harvard Law School.

${ }^{1}$ Kevin M. Clermont \& Stewart J. Schwab, How Employment Discrimination Cases Fare in Federal Court, 1 J. Empirical Legal Stud. 429, 446-55 (2004); Kevin M. Clermont \& Theodore Eisenberg, Plaintiphobia in the 
but the goal in that work was not to present a reasonably comprehensive picture, in the spirit of this Symposium, of trial-related federal appellate litigation.

Systematic reports about appeals of trials are rare because data about the mass of cases, from the trial stage through the appellate stage, have not been available. This article uses federal data sets covering trial court activity and appellate court activity for cases terminating in fiscal years 1988 through 2000. To summarize some key findings for the period studied, 10.9 percent of all cases filed are appealed, a figure that rises to 21.0 percent if one limits the universe of cases to those with a definitive judgment for plaintiff or defendant. Appeal rates vary substantially between tried and untried cases. For tried cases, the appeal rate is 39.6 percent compared to 10.0 percent of nontried cases. Since so many nontried cases end in settlements, ${ }^{2}$ a more relevant figure may be those cases ending in definitive judgment for plaintiff or defendant (though these too include some settlements). For cases with such judgments, the appeal rate is 19.0 percent in nontried cases and 40.9 percent in tried cases.

Filing an appeal does not necessarily mean pursuing it to conclusion. The rate of appeals pursued to a judgment on the merits by the appellate courts is about onehalf the raw rate of appeals. Tried cases with definitive judgments are appealed through a conclusion on the merits in 22.7 percent of concluded trials. In comparison, 10.2 percent of nontried cases with trial court definitive judgments end with appellate decisions on the merits. Appeals, like district court filings, have a substantial rate of dropouts, through settlement or withdrawal. These figures differ as between plaintiffs and defendants, as more fully described below. Defendants appear to appeal judgments for plaintiffs at higher rates than plaintiffs appeal judgments for defendants. Defendants appeal to conclusion on the merits 26.4 percent of tried cases with judgments for plaintiffs. Plaintiffs appeal to conclusion on the merits 19.7 percent of tried cases with judgments for defendants. These figures vary across case categories.

Appeals courts affirm and reverse at substantially different rates appeals from judgments for plaintiffs and defendants. On appeal from trials, defendants achieve reversal of adverse trial court judgments at a greater rate than plaintiffs. Defendants achieve reversal in about 10 percent of all filed cases ending in adverse trial judgments and suffer affirmance in about 15 percent of such cases. This yields a reversal

Appellate Courts: Civil Rights Really Do Differ from Negotiable Instruments, 2002 Univ. Ill. L. Rev. 947; Kevin M. Clermont \& Theodore Eisenberg, Appeal from Jury or Judge Trial: Defendants' Advantage, 3 Am. L. \& Econ. Rev. 125, 130 (2001); Kevin M. Clermont \& Theodore Eisenberg, Anti-Plaintiff Bias in the Federal Appellate Courts, 84 Judicature 128 (2000).

${ }^{2}$ For estimates of settlement rates and the difficulty in ascertaining such rates, see Gillian K. Hadfield, Where Have All the Trials Gone? Settlements, Nontrial Adjudications and Statistical Artifacts in the Changing Disposition of Federal Civil Cases, 1 J. Empirical Legal Stud. 705 (2004); Theodore Eisenberg \& Stewart Schwab, Explaining Constitutional Tort Litigation: The Influence of the Attorney Fees Statute and the Government as Defendant, 73 Cornell L. Rev. 719 (1988). 
rate of about 40 percent in defendants' appeals of trials. Plaintiffs achieve reversal in about 4 percent of all filed cases ending in trial judgments and suffer affirmance in about 16 percent of such cases. This yields a reversal rate of about 18 percent in plaintiffs' appeals of trials. A similar difference between plaintiffs and defendants exists in appeals of nontried cases. Reversal rates, like appeal rates, vary across case categories.

The first three parts of the this article are monographic in nature. Part I describes the data analyzed. Part II reports on appeal rates and outcomes for the data aggregated together. Part III reports on appeal rates and outcomes for several large case categories. Part IV begins to explore the reasons for observed levels of reversal rates in appeals by plaintiffs and defendants by a case study of employment discrimination cases.

\section{THE DATA}

Data gathered by the Administrative Office of the U.S. Courts (AO), assembled by the Federal Judicial Center, and disseminated by the Inter-university Consortium for Political and Social Research convey the outcomes of all cases terminated in the federal courts since fiscal year 1970. Federal court clerks transmit to the Administrative Office data about each case. ${ }^{3}$ The data include the names of the parties, the subject-matter category and the jurisdictional basis of the case, the case's origin in the district as original or removed or transferred, the amount demanded, the dates of filing and termination in the district court or the court of appeals, the procedural stage of the case at termination, the procedural method of disposition, and, if the court entered judgment or reached decision, who prevailed.

Data covering fiscal years 1988-2000 allow tracing cases from the district court to the appellate level. ${ }^{4}$ For some purposes, however, it is necessary to discard appeals from the more recent years in the data set. One primary goal is to trace through appeal the outcome of completed trials. A trial outcome cannot be appealed until

\footnotetext{
${ }^{3}$ See Inter-university Consortium for Policy \& Soc. Research, Federal Court Cases: Integrated Data Base, 2001, ICPSR Study No. 3415 (2002) [hereinafter ICPSR 3415]; Inter-university Consortium for Policy \& Soc. Research, Federal Court Cases: Integrated Data Base, 1970-2000, ICPSR Study No. 8429 (2001) [hereinafter ICPSR 8429]. For additional information on the federal courts' record keeping, see Tech. Training \& Support Div., Admin. Office of the U.S. Courts, Civil Statistical Reporting Guide (July 1999) (on file with authors) [hereinafter Civ. Stat. Reporting Guide]; 11 Admin. Office of the U.S. Courts, Guide to Judiciary Policies and Procedures, at II-18 to -28 (1985) (district courts) (on file with authors); 11 Admin. Office of the U.S. Courts, Statistics Manual 7-43 (1989) (courts of appeals). For an evaluation of the reliability of the database, see Theodore Eisenberg \& Margo Schlanger, The Reliability of the Administrative Office of the U.S. Courts Database: An Empirical Analysis, 78 Notre Dame L. Rev. 1455 (2003).

${ }^{4}$ Only in fiscal year 1988 did the AO start including the district court docket number in its courts of appeals data set.
} 
the trial is completed. Tried cases take, on average, about two years from filing to termination in the district courts. Appealed cases take many additional months to conclude appellate proceedings. Cases filed in, for example, 2000, that might ultimately be tried will tend not to have reached trial by the end of fiscal year 2000, much less to have concluded an appeal. So for cases filed in recent years, the district court data is biased by not having allowed enough time for triable cases to run their course; and the appellate court sample will be biased by not having allowed appealed cases to run their course. Since, on average, tried cases take longer to complete than nontried cases, the appellate database's underrepresentation of tried cases can be extreme. To address these data-censoring issues, the study of raw appeal rates includes only district court filing years in which filed cases have had sufficient time to reach trial and to be appealed. This yields a 10-year sample of cases filed from 1987 through 1996. To study appellate outcomes, the sample is reduced by an additional year and covers district court cases filed from 1987 through $1995 .{ }^{5}$

For purposes of this study, a few definitions are useful. First, the appeal rate is, in general, the percentage or proportion of filed district court cases that reach the appellate court docket, regardless of whether the appellate court ultimately resolves the appeal on the merits. A second appeal rate limits the focus to cases filed in the district court that resulted in a judgment for either plaintiff or defendant. If the judgment below was for plaintiff, this study treats the defendant as the appellant. ${ }^{6}$ If the judgment below was for defendant, this study treats the plaintiff as the appellant.

\footnotetext{
${ }^{5}$ Another approach to the data focuses not on the year of district court filing but on the year of appellate court termination. This is a satisfactory alternative for examining the makeup of appellate docket characteristics, such as the percent of appellate terminations that are from tried cases. For analyses that include trial court activity, however, censoring will be severe for the early years of the matched trial-appellate court data set. For example, the 1987 data contain a censored pattern of tried cases (for lack of district court docket numbers in the appellate data). Only tried cases that correspond to appeals docketed in 1987 can be matched to appeals. So the matched appellate data substantially underrepresent tried (and other) cases that reached the appellate docket before 1987. A study based on appellate termination year would have to omit four to five years of data at the beginning of the matching period.
}

${ }^{6}$ Prior analysis of a district court-appellate court matched data set reported that examining the parties' names revealed that more than a quarter of the appeals from judgment for plaintiff have a dissatisfied plaintiff as appellant. Id. That study, primarily interested in outcomes on appeal, simply discarded such appeals to avoid possibly misleading effects on appellate-reversal rates. Excluding such cases had little effect because the reversal rate for that special category of appeals was virtually identical to the defendants' reversal rate. Further evidence suggests, as a first pass, that one can support treating these special appeals as in fact largely judgments for plaintiffs. First, the magnitude of this special class of appeals is smaller than originally thought. Coding errors with respect to the order of the parties' names in the Fifth Circuit for cases terminated in the trial courts from 1987 through 1994 spuriously increases the estimate of plaintiff appeals of plaintiff judgments from 23.9 percent to 30.7 percent of plaintiff appeals. So at most less than one-quarter of plaintiff appeals are of judgments for plaintiffs. Second, evidence about the reliability of the AO's coding of for whom judgment was entered is now available. In tort trials terminated in 2000, the AO's coding is correct in over 95 percent of the cases. Eisenberg \& Schlanger, supra note 3. That same study casts doubt on the AO coding of judgments in prisoner cases in 1993 that are coded as judgments for plaintiffs with zero awards. Id. So further analysis of error patterns might proceed on a case-category basis. Third, when judgment is in fact 
Second, distinguish mere appearance on the appellate docket, used to define the appeal rate, from appellate resolution on the merits. The rate of appeals-toconclusion is the percentage or proportion of district court filings that reach an appellate conclusion on the merits.

Third, the reversal rate is the proportion or percentage of appeals that reach a decisive outcome and that emerge as reversed rather than affirmed. The appellate outcome of "reversed" is defined as comprising the three codes for reversed, remanded, and affirmed in part and reversed in part. The appellate outcome of "affirmed" is defined as comprising only the codes for affirmed and dismissed on the merits. One can readily calculate a plaintiffs' reversal rate and a defendants' reversal rate or their corresponding affirmance rates.

\section{AgGregate Empirical Results}

This part reports appeal rates and outcomes for all categories of cases aggregated together. It first shows appeal and reversal rates and then discusses the sensitivity of results to the methodology used to match district court and appellate court cases. It then explores time trends in appeal rates, analyzed both in the aggregate and subdivided by plaintiff-defendant status.

\section{A. Basic Appeal and Reversal Rates}

Table 1, Panel A, summarizes appellate activity in relation to trial court filings. Its first numerical column shows about 2.4 million district court filings from calendar years 1987 through 1996. Of these, the table's second numerical column shows that parties eventually filed appeals in 10.9 percent of the filings. The overall appeal rate's two major components are a 39.6 percent appeal rate in cases resolved after trial and a 10.0 percent appeal rate in cases resolved without trial. Many more cases end without trial than with trial so the appeal rate in nontried cases dominates in calculating the overall appeal rate.

Panel B limits the sample to cases in which the AO data indicate the district court case ended with a judgment for plaintiff or defendant. ${ }^{7}$ These data thus exclude cases withdrawn before judgment, cases settled without entry of judgment, or cases lacking judgments for any other reason. It shows an appeal rate for all cases combined of 21.0 percent, nearly twice the rate of the Panel A sample that includes all cases. Panel B's greater appeal rate comes almost entirely from cases that did not

entered for plaintiff, inferring a plaintiff appeal solely from the order of the parties' names likely overstates the degree of the problem. As noted in prior work, in appellate outcomes, such cases "behaved" in outcome like true defendant appeals. Clermont \& Eisenberg, Plaintiphobia, supra note 1.

${ }^{7}$ Other possible judgment codes are none (or missing), judgment for neither, or judgment for both. 
Table 1: Federal District Court Filings, Appeal Rates, Appellate Outcomes

\begin{tabular}{|c|c|c|c|c|c|c|}
\hline & \multicolumn{2}{|c|}{$\begin{array}{c}\text { District Court Filings, } \\
\text { Appeal Rate, } \\
1987-1996\end{array}$} & \multicolumn{4}{|c|}{$\begin{array}{l}\text { District Court Filings, Appeals to Conclusion, } \\
\text { Affirmances, Reversals, 1987-1995 }\end{array}$} \\
\hline & $\begin{array}{l}\text { Number of } \\
\text { Filings }\end{array}$ & Appealed & $\begin{array}{l}\text { Number of } \\
\text { Filings }\end{array}$ & $\begin{array}{l}\text { Appealed to } \\
\text { Conclusion }\end{array}$ & Affirmed & Reversed \\
\hline A. All Cases & $2,357,591$ & $10.9 \%$ & $2,101,374$ & $5.6 \%$ & $4.3 \%$ & $1.3 \%$ \\
\hline Trials & 74,253 & $39.6 \%$ & 68,060 & $22.1 \%$ & $14.8 \%$ & $7.3 \%$ \\
\hline Judge trials & 33,719 & $38.3 \%$ & 31,460 & $21.9 \%$ & $15.4 \%$ & $6.5 \%$ \\
\hline Jury trials & 40,534 & $40.8 \%$ & 36,600 & $22.4 \%$ & $14.3 \%$ & $8.0 \%$ \\
\hline All nontrials & $2,283,338$ & $10.0 \%$ & $2,033,314$ & $5.0 \%$ & $4.0 \%$ & $1.0 \%$ \\
\hline $\begin{array}{l}\text { B. All Cases with Judgment } \\
\text { for Plaintiff or Defendant }\end{array}$ & 707,776 & $21.0 \%$ & 639,727 & $11.4 \%$ & $8.8 \%$ & $2.5 \%$ \\
\hline Trials & 65,138 & $40.9 \%$ & 59,648 & $22.7 \%$ & $15.4 \%$ & $7.3 \%$ \\
\hline Judge trials & 29,069 & $39.5 \%$ & 27,092 & $22.6 \%$ & $16.2 \%$ & $6.4 \%$ \\
\hline Jury trials & 36,069 & $41.9 \%$ & 32,556 & $22.9 \%$ & $14.8 \%$ & $8.1 \%$ \\
\hline All nontrials & 642,638 & $19.0 \%$ & 580,079 & $10.2 \%$ & $8.2 \%$ & $2.0 \%$ \\
\hline
\end{tabular}

Note: Panel A summarizes appellate activity in relation to federal district court filings. The first two numerical columns show the total number of filings and the percent of filings for which a notice of appeal was filed, regardless of whether the appeal was pursued to conclusion on the merits. The last four numerical columns relate the number of filings to cases appealed to conclusion on the merits. They use one less year of filing data than do the first two columns to allow more appealed cases to conclude before computing appeal-to-conclusion rates. Panel B reports the same information as Panel A but limits the sample to cases in which the $\mathrm{AO}$ data indicate the district court case ended with a judgment for plaintiff or defendant.

Source: Administrative Office of the U.S. Courts. The district court data and the appellate court data are matched without trying to account for multiple instances of docket numbers and other plausible matching techniques. See Table 2 for results that try to account for the subtleties of matching the two levels of data.

reach trial. Nineteen percent of nontried cases reaching judgment for plaintiffs or defendants are appealed, compared to Panel A's 10 percent of cases not limited to judgments. Appeal rates in tried cases are only slightly higher than appeal rates in Panel A because tried cases tend to end with the entry of judgments for plaintiff or defendant.

Table 1's last four columns focus on cases that are appealed through conclusion on the merits-cases in which the appeals court enters an order affirming or reversing the trial court. As discussed above, since appeals to conclusion take longer than mere appeals, the sample for purposes of this analysis ends with district court cases filed in 1995. So these columns analyze the 2.1 million filings from 1987 through 1995.

Panel A shows that about half the appeals filed terminate without definitive appeals court resolution. For example, Panel A's first row (fourth numerical column) shows that 5.6 percent of district court filings are appealed to conclusion, compared to 10.9 percent of all cases having appeals filed. The appeals drop-out rate is not dramatically different for tried and nontried cases. About half of each group's appellate filings end without adjudication on the merits by the appellate court. Panel B's pattern of drop-out appeals does not materially differ from Panel A's. About half the 
appeals filed from cases with judgments for plaintiffs or defendants do not reach definitive appellate court resolution.

Table 1's last two columns show the percentage of district court filings from 1987 through 1995 that end with an affirmance or reversal. Panel A's first row shows that 4.3 percent of the 2.1 million district court filings ended with an appellate court affirming the trial court and that 1.3 percent of such filings ended with an appellate court reversing the trial court. Thus, in rounded figures, 1 filing in 100 yields an appellate reversal. Simple computation reveals that about one-quarter of 1 percent of all cases filed from 1987 through 1995 led to an appellate court reversal of a trial outcome and that about one-half of 1 percent of such filed cases led to an appellate court affirmance of a trial outcome.

Panel B shows substantially increased reversal rates for cases ending with judgments for plaintiffs or defendants. Its first row shows that appellate courts reverse trial court judgments in 2.5 percent of the 639,727 filed cases ending in judgments for plaintiffs or defendants. About two-thirds of 1 percent of all filed cases ending with judgment for plaintiff or defendant led to an appellate reversal of a trial court outcome; a bit more than 1 percent of such filed cases led to an appellate court affirmance of a trial court outcome.

Each panel shows that about 7 percent of filed cases ending in trials lead to an appellate court reversal, and that the reversal percent is about 6 percent for judge trials and 8 percent for jury trials.

\section{B. Sensitivity of Results to Methodology Used to Match Appellate and Trial Court Outcomes}

Table 1's figures are sensitive to how the district court and appellate court data are matched. Matching massive trial and appellate data sets is an imperfect science. Earlier work refined the matched data set to eliminate duplicate case records, and adjusted for cross, consolidated, and reopened appeals. ${ }^{8}$ Duplicate case records identified as duplicates based on repeated docket numbers are not necessarily mistakes. Cases and their docket numbers properly can appear in the system more than once. For example, a terminated district court filing might be appealed and remanded, thereby generating, for record-keeping purposes, a new case with the same district court docket number. This appeal-remand-reoriginate process can happen more than once in a single case. A single district court case might in the first instance generate appeals by multiple parties, thereby leading several different appellate court docket numbers to match a single district court docket number. Those appellate cases may or may not be consolidated. The analysis leading to Table 1 accepts the federal data sets as they have been entered; the district court and appellate court data set matches are unfiltered. The principal motivation is to allow comparing the numbers of cases against published $\mathrm{AO}$ data to provide some measure of reliability

\footnotetext{
${ }^{8}$ Clermont \& Eisenberg, Plaintiphobia, supra note 1.
} 
Table 2: Federal District Court Filings, Appeal Rates, Appellate Outcomes Using Stricter Matching Criteria

\begin{tabular}{|c|c|c|c|c|c|c|}
\hline & \multicolumn{2}{|c|}{$\begin{array}{c}\text { District Court Filings, } \\
\text { Appeal Rate, } \\
\text { 1987-1996 }\end{array}$} & \multicolumn{4}{|c|}{$\begin{array}{l}\text { District Court Filings, Appeals-to-Conclusion, } \\
\text { Affirmances, Reversals, 1987-1995 }\end{array}$} \\
\hline & $\begin{array}{l}\text { Number of } \\
\text { Filings }\end{array}$ & Appealed & $\begin{array}{l}\text { Number of } \\
\text { Filings }\end{array}$ & $\begin{array}{l}\text { Appealed to } \\
\text { Conclusion }\end{array}$ & Affirmed & Reversed \\
\hline A. All Cases & $2,298,153$ & $8.5 \%$ & $2,046,869$ & $4.4 \%$ & $3.7 \%$ & $0.7 \%$ \\
\hline Trials & 64,086 & $28.2 \%$ & 58,594 & $14.9 \%$ & $11.7 \%$ & $3.3 \%$ \\
\hline Judge trials & 29,578 & $28.0 \%$ & 27,570 & $15.2 \%$ & $12.4 \%$ & $2.8 \%$ \\
\hline Jury trials & 34,508 & $28.4 \%$ & 31,024 & $14.7 \%$ & $11.0 \%$ & $3.7 \%$ \\
\hline All nontrials & $2,234,067$ & $8.0 \%$ & $1,988,275$ & $4.1 \%$ & $3.5 \%$ & $0.6 \%$ \\
\hline $\begin{array}{l}\text { B. All Cases with Judgment } \\
\text { for Plaintiff or Defendant }\end{array}$ & 674,777 & $16.6 \%$ & 609,440 & $9.0 \%$ & $7.6 \%$ & $1.5 \%$ \\
\hline Trials & 56,205 & $29.6 \%$ & 51,355 & $15.6 \%$ & $12.3 \%$ & $3.3 \%$ \\
\hline Judge trials & 25,544 & $29.6 \%$ & 23,788 & $16.0 \%$ & $13.2 \%$ & $2.8 \%$ \\
\hline Jury trials & 30,661 & $29.6 \%$ & 27,567 & $15.4 \%$ & $11.6 \%$ & $3.8 \%$ \\
\hline All nontrials & 618,572 & $15.4 \%$ & 558,085 & $8.4 \%$ & $7.2 \%$ & $1.3 \%$ \\
\hline
\end{tabular}

Note: Panel A summarizes appellate activity in relation to federal district court filings. The first two numerical columns show the total number of filings and the percent of filings for which a notice of appeal was filed, regardless of whether the appeal was pursued to conclusion on the merits. The last four numerical columns relate the number of filings to cases appealed to conclusion on the merits. They use one less year of filing data than do the first two columns to allow more appealed cases to conclude before computing appeal-to-conclusion rates. Panel B reports the same information as Panel A but limits the sample to cases in which the AO data indicate the district court case ended with a judgment for plaintiff or defendant.

SourcE: Administrative Office of the U.S. Courts. The matching of the district court and appellate court data attempts to eliminate duplicate case records, and adjusts for cross, consolidated, and reopened appeals. See Table 1 for results based on matching the district court and appellate court data without such refinements.

to the analysis and I estimate that at least 85 percent of cases appearing on the appellate docket have been matched to a district court case.

However, the restrictiveness with which one matches district court and appellate court cases has nontrivial effects on appeal rates and other numbers. Table 2 reports the same information as Table 1, now calculated using a more restrictive approach to matching the data. Table 2's total of about 2.4 million filings from 1987 through 1996 is about 60,000 less than the number of filings shown in Table 1. This is about 2.5 percent fewer cases, not a startling high figure. The reduction, however, is not uniformly distributed across case filings. Table 2 shows over 97 percent of the total filings shown in Table 1, but it shows only about 86 percent of the number of filings leading to trials (64,086 in Table 2 compared to 74,253 in Table 1). So the matching process affects tried cases more substantially than it affects nontried cases.

The columns reporting appeals to conclusion further illustrate the disproportionate effect on tried cases. Table 1 reports that 39.6 percent of tried cases are appealed and that 22.1 percent of tried cases are appealed to conclusion; Table 2 
reports that 28.2 percent of tried cases are appealed and 14.9 percent of tried cases are appealed to conclusion. It is reasonable to limit the pool of appealable cases to those cases ending with judgments. Using these figures, the appeal rate from trial outcomes appears about 50 percent higher using less strict case matching than using stricter case matching.

The defendant advantage in appellate outcomes from trials exists using either matching technique but its magnitude changes. Table 1, Panel B's second row shows that 15.4 percent of case filings from 1987 through 1995 end with appellate affirmance and 7.3 percent end with appellate reversal. Table 2, Panel B's second row shows corresponding figures of 12.3 percent and 3.3 percent. The reversal rate thus changes from 32.1 percent to 21.2 percent.

This article uses the less-strict matching convention summarized in Table 1. But the differences between Table 1 and Table 2 may have important implications that warrant separate research. Simple calculations show that the matching technique employed has varying effects across different groups of cases. Table 1's first row reports a total of 2,357,951 filings from 1987 through 1996. Table 2's stricter matching criteria shows 2,298,153 filings for the same period. The difference of 59,798 filings represents 2.5 percent of all filings. If one uses the Panel B judgmentbased data, Table 1 shows 707,776 filings leading to judgment for plaintiff or defendant. Table 2 shows 674,777 , a reduction of 4.7 percent. If one limits the sample to cases resolved at trial per panel B, Table 1 shows 65,138 filings and Table 2 shows 56,205 filings, a reduction of 13.7 percent, with jury trials somewhat more affected than judge trials.

The varying differences suggest that relatively few cases active in the system, those that generate matches filtered out by the strict matching criteria, substantially influence observed rates of appeal, appeals to conclusion, and appellate outcomes. The matching methodology affects tried cases more than other cases. Aside from the raw numbers noted above, Table 1 shows an appeal rate of 40.9 percent in tried cases. Table 2's effort to more strictly match appellate court and trial court data yields an appeal rate of 29.6 percent in tried cases. Similarly, the appeal-to-conclusion rate in tried cases drops from 22.7 percent in Table 1 to 15.6 percent in Table 2. That the matching methodology disproportionately affects tried cases is not surprising. Tried cases are more contested than other cases and thus are more likely to generate successive activity at both the trial and appellate levels.

\section{Time Trends}

The time trend of decreasing trial activity is a central theme of this Symposium. The relatively recent ability to match federal district court and appellate data, and the censoring issues discussed above, limit the time period available to study appellate activity to about one decade. Figures 1 through 3 examine time trends during that time period. 
Figure 1: Appeal rates, trials and nontrials, federal courts, 1987-1996.

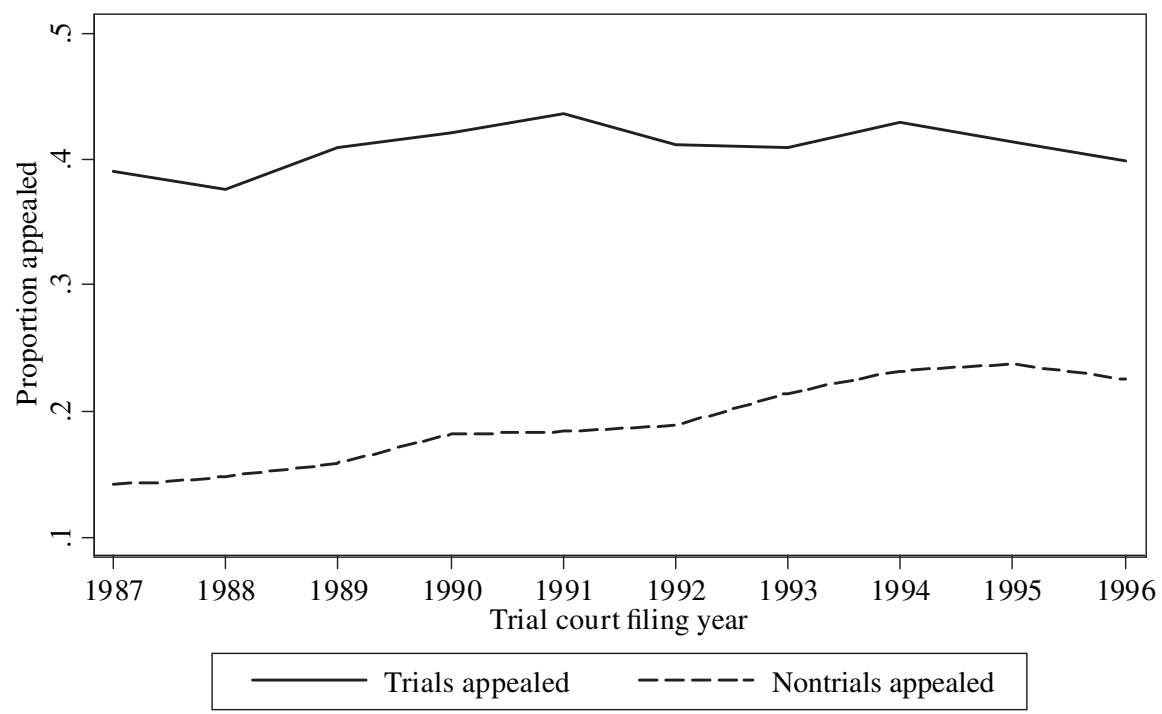

Note: Appeal rates are based on the number of district court filings and trials, and the number of appeals filed, regardless of whether the appeals were pursued to a conclusion on the merits. The convention used to match district court and appellate court cases is that followed in Table 1.

Source: Administrative Office of the U.S. Courts.

Figure 1 indicates that, over the covered decade, the rate of appeals docketed from tried cases has remained level at about 40 percent of trial outcomes. The rate of appeals docketed from nontried cases has increased from less than 15 percent to over 20 percent. The constant rate of appeal in tried cases, combined with the declining number of trials shown in Marc Galanter's article, ${ }^{9}$ suggests that the absolute number of tried cases adjudicated on appeal should be declining.

Figure 2 explores the number of appeals and shifts the focus from the existence of an appellate filing to the existence of an appeal to conclusion on the merits. It shows the number of trials appealed to conclusion in decline from 1987 through 1995. (Because tried cases take longer to conclude on average than nontried cases, I limit the tried-case sample to cases ending through 1995, thus limiting the censoring effect of tried cases filed in the years studied that did not have sufficient time to

${ }^{9}$ Marc S. Galanter, The Vanishing Trial: An Examination of Trials and Related Matters in Federal and State Courts, 1 J. Empirical Legal Stud. 459 (2004). 
Figure 2: Number of appeals from trials and nontrials, federal courts, 1987-1996.

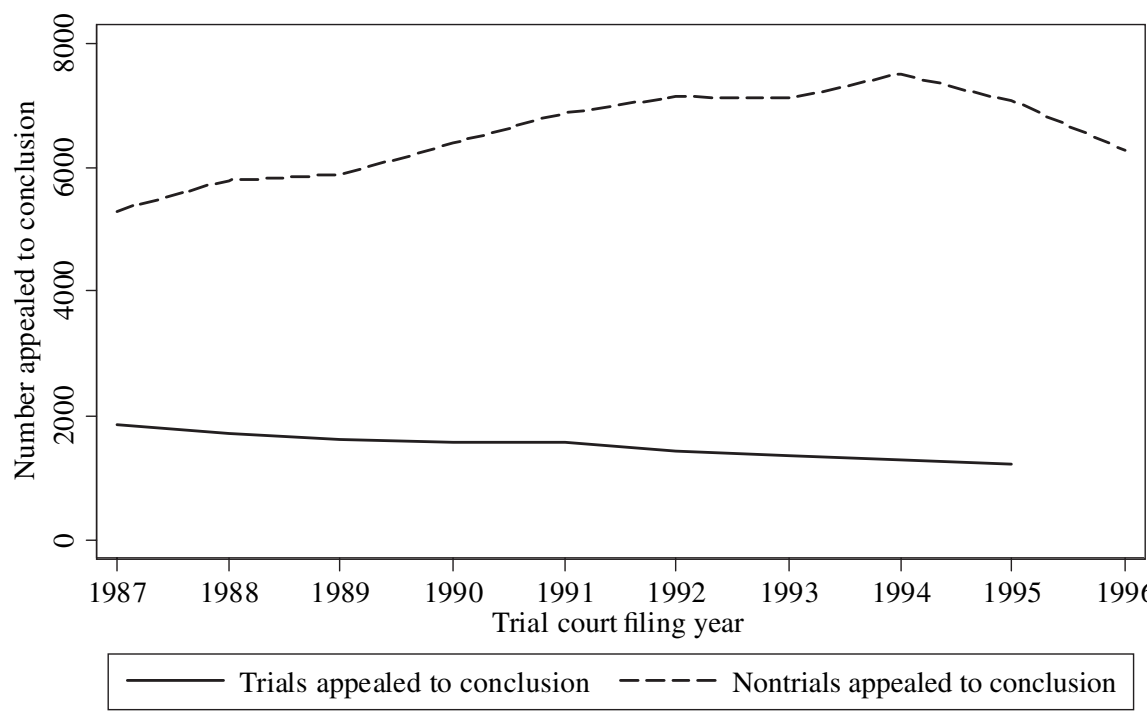

Note: The number of appeals is limited to appeals that were pursued to a conclusion on the merits. The convention used to match district court and appellate court cases is that followed in Table 1.

Source: Administrative Office of the U.S. Courts.

conclude in the district court and be pursued to appellate conclusion.) Of cases filed in 1987, more than 1,800 tried cases were appealed to conclusion. For cases filed in 1995, the number had dropped to about 1,200. In contrast, the number of nontried cases appealed is higher for cases filed in 1996 than in 1987, having grown from around 5,300 in 1987 to about 7,100 in 1995 and about 6,300 in 1996.

The declining number of trial appeals and increasing number of nontrial appeals combine to reduce the tried-case proportion of appealed cases, as shown in Figure 3. For cases filed in 1987, tried cases comprised over 25 percent of cases appealed to conclusion. For cases filed in 1995, tried cases were less than 15 percent of concluded appeals.

\section{Variation by Plaintiff-Defendant Status}

The data described above are aggregated without distinguishing between plaintiff and defendant behavior. Appeal rates and outcomes differ, sometimes substantially, depending on whether plaintiffs or defendants are appealing. Table 3 reports the same items of information as Table 1 but divides the data by whether cases ended 
Figure 3: Proportion of concluded appeals that are from trials, federal courts, 1987-1995.

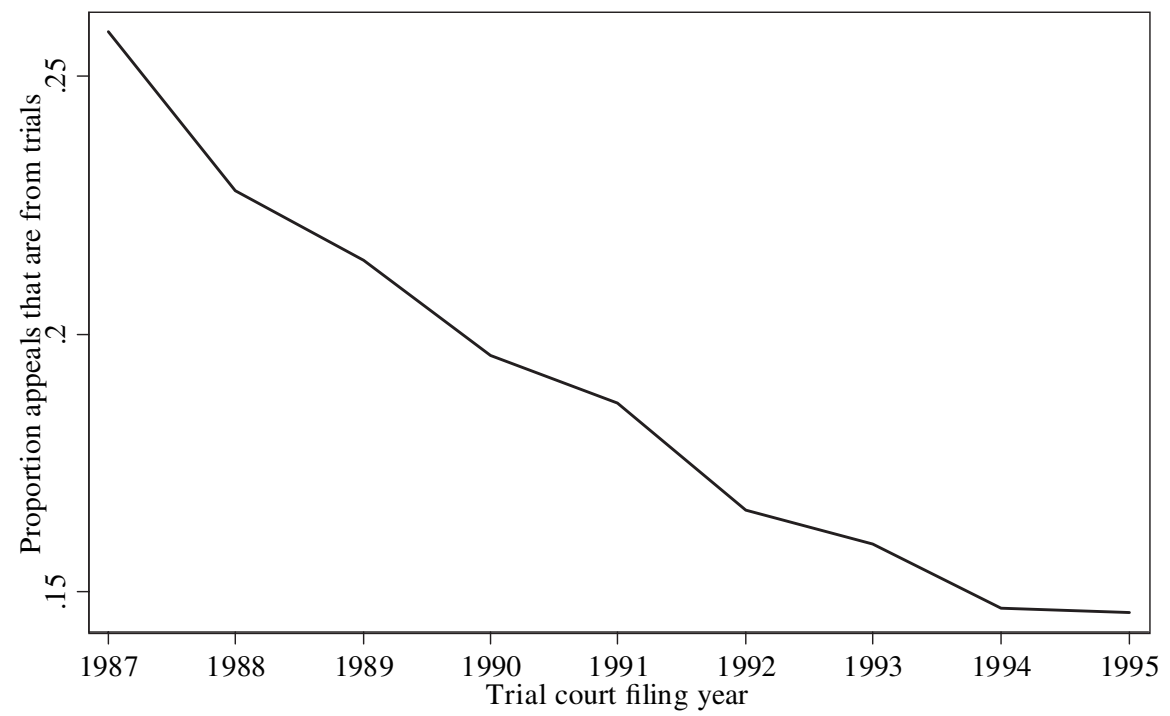

NoтE: The number of appeals is limited to appeals that were pursued to a conclusion on the merits. The convention used to match district court and appellate court cases is that followed in Table 1.

Source: Administrative Office of the U.S. Courts.

with judgments for plaintiffs, reported in Panel A, or with judgments for defendants, reported in Panel B.

The two panels' first rows indicate that, aggregated across all stages of disposition, plaintiffs appeal at nearly three times the rate of defendants. The "Appealed to Conclusion" column indicates that 16.1 percent of all filed cases lead to plaintiff appeals of judgments for defendants. That column also indicates that 5.7 percent of all filed cases lead to defendant appeals of judgments for plaintiffs.

These cumulative figures vary substantially for tried and nontried cases. The massive number of nontried cases drives the cumulative figures. Both panels show that (1) the number of nontried cases dwarfs the number of tried cases, and (2) that the higher rate of plaintiff appeals is limited to nontried cases.

For example, Panel A shows that, for filings from 1987 through 1995, 263,328 district court nontried cases ended with judgments for plaintiffs and only 27,200 district court trials ended with judgments for plaintiffs. Panel B similarly shows that, for the same time period, 316,751 district court nontried cases ended with judgments 
Table 3: Appeal Rates and Appellate Outcomes, Federal Filings, 1987-1996, Stated Separately for Plaintiffs and Defendants

\begin{tabular}{lrrrrrr}
\hline & $\begin{array}{c}\text { Number of } \\
\text { Judgments, } \\
1987-1996\end{array}$ & $\begin{array}{c}\text { Number of } \\
\text { Judgments, } \\
1987-1995\end{array}$ & $\begin{array}{c}\text { Appealed, } \\
1987-1996\end{array}$ & $\begin{array}{c}\text { Appealed to } \\
\text { Conclusion, } \\
1987-1995\end{array}$ & Affirmed & Reversed \\
\hline A. Judgments for Plaintiffs & & & & & & \\
All cases & 313,958 & 290,528 & $10.7 \%$ & $5.7 \%$ & $3.4 \%$ & $2.2 \%$ \\
Trials & 29,597 & 27,200 & $47.9 \%$ & $26.4 \%$ & $14.6 \%$ & $11.8 \%$ \\
$\quad$ Judge trials & 12,679 & 11,808 & $44.8 \%$ & $24.6 \%$ & $14.6 \%$ & $9.9 \%$ \\
$\quad$ Jury trials & 16,918 & 15,392 & $50.2 \%$ & $27.9 \%$ & $14.6 \%$ & $13.2 \%$ \\
All nontrials & 284,361 & 263,328 & $6.8 \%$ & $3.5 \%$ & $2.3 \%$ & $1.2 \%$ \\
B. Judgments for Defendants & & & & & $16 \%$ & \\
All cases & 393,818 & 349,199 & $29.2 \%$ & $16.1 \%$ & $13.3 \%$ & $2.8 \%$ \\
Trials & 35,541 & 32,448 & $35.0 \%$ & $19.7 \%$ & $16.1 \%$ & $3.6 \%$ \\
$\quad$ Judge trials & 16,390 & 15,284 & $35.4 \%$ & $21.0 \%$ & $17.4 \%$ & $3.6 \%$ \\
$\quad$ Jury trials & 19,151 & 17,164 & $34.6 \%$ & $18.5 \%$ & $15.0 \%$ & $3.5 \%$ \\
All nontrials & 358,277 & 316,751 & $28.7 \%$ & $15.7 \%$ & $13.0 \%$ & $2.7 \%$ \\
\hline
\end{tabular}

Note: Panel A summarizes activity in relation to federal district court filings that ended with judgments for plaintiffs. The number of judgments is the number of district court cases ending with judgment for plaintiffs at the indicated procedural stages. Appeal rates in the third numerical column include district court cases filed from 1987 through 1996. Appeal-to-conclusion rates and appellate outcomes in the last three numerical columns include district court cases filed from 1987 through 1995. The shorter time period is used to help account for the time necessary to allow an appellate case to reach conclusion. A nontrivial portion of district court filings in 1996 might not have had sufficient time to reach judgment and be appealed to conclusion by the cut-off date of these data. Panel B summarizes activity in relation to federal district court filings that ended with judgments for defendants.

Source: Administrative Office of the U.S. Courts. District court and appellate court files are matched without filtering based on consolidation of appeals, docket numbers that reappear in the data sets, or other criteria, as in Table 1.

for defendants and 32,448 district court trials ended with judgments for defendants. In tried cases, by contrast, Panel A's second numerical row shows that defendants appealed to conclusion 26.4 percent of adverse trial judgments. Panel B's corresponding row shows that plaintiffs appealed to conclusion 16.1 percent of adverse trial judgments.

Table 3 also shows that the pattern of affirmances and reversals varies for plaintiffs and defendants. In tried cases, Panel A's second numerical row shows that 14.6 percent of judgments for plaintiffs were affirmed after defendant appeals and 11.8 percent of judgments for plaintiffs were reversed after appeal. Panel B's second numerical row shows that judgments for defendants are less prone to reversal, with 16.1 percent of tried cases leading to appellate affirmance and 3.6 percent of tried cases leading to appellate reversal. Using these percents, the reversal for defendant appeals of plaintiff trial judgments is 45 percent and the reversal rate for plaintiff appeals of defendant trial judgments is 18 percent. The two panels also show that a similar asymmetrical reversal pattern exists for appeals of nontried cases. 
Table 4: Appeal Rates and Reversal Rates, by Major Case Category, Federal Filings Leading to Trials, 1987-1995

\begin{tabular}{|c|c|c|c|c|}
\hline & \multicolumn{2}{|c|}{ Rate of Trial Losses Appealed by } & \multicolumn{2}{|c|}{ Reversal Rate in Appeals by } \\
\hline & Plaintiffs & Defendants & Plaintiffs & Defendants \\
\hline Contract & $20.8 \%$ & $27.2 \%$ & $26.3 \%$ & $37.9 \%$ \\
\hline Tort & $19.2 \%$ & $21.0 \%$ & $15.8 \%$ & $46.7 \%$ \\
\hline Civil rights & $24.4 \%$ & $33.0 \%$ & $14.3 \%$ & $50.3 \%$ \\
\hline Prisoner & $15.0 \%$ & $26.0 \%$ & $9.3 \%$ & $41.2 \%$ \\
\hline Labor & $22.6 \%$ & $32.2 \%$ & $25.2 \%$ & $46.3 \%$ \\
\hline Intellectual property & $17.8 \%$ & $21.5 \%$ & $32.8 \%$ & $36.7 \%$ \\
\hline
\end{tabular}

Note: The numbers underlying the table's percentages are reported in the Appendix tables. The percentages summarize activity in relation to federal district court filings that ended with trial judgments for plaintiffs or defendants in district court cases filed from 1987 through 1995 . Reversal rates are based on cases appealed to conclusion.

Source: Administrative Office of the U.S. Courts. District court and appellate court files are matched without filtering based on consolidation of appeals, docket numbers that reappear in the data sets, or other criteria, as in Table 1.

\section{VARIATION ACROSS CASE CATEgORIES}

This part separates the data by major case category. For each of six major case categories (contract, tort, civil rights, prisoner, labor, and intellectual property), ${ }^{10}$ the Appendix reports data analogous to those reported in Table 3. Table 4 summarizes some of the key category-specific results. It shows that, in each of the six major categories, defendants tend to appeal trial losses to conclusion more than plaintiffs. It also shows that, in each category, defendants succeed on appeal at a higher rate than plaintiffs.

\section{A. Time Trends by Case Category}

Figures 4 through 6 explore possible time trends in the data for the six major case categories. The figures suggest that some core results in the aggregated data persist at the level of these major case categories. They also help identify the case categories that contribute to the aggregate trends shown in Part II.

Figure 4 focuses on the docketing of an appeal and not on pursuing an appeal to conclusion. It shows that, for the period studied, appeal rates from tried cases exceed appeal rates from nontried cases in every category in every year. The difference in appeal rates between tried and nontried cases is relatively small in civil rights

\footnotetext{
${ }^{10}$ The major categories consist of the following Administrative Office category numbers: contract-100, 110, 120, 130, 140, 160, 190, and 193; tort-310-385; prisoner-510-555; civil rights-440-443; labor-710-791; intellectual property—820, 830, and 840. Civ. Stat. Reporting Guide, supra note 3.
} 
Figure 4: Appeal rate, by case category, district court filings, 1987-1996.

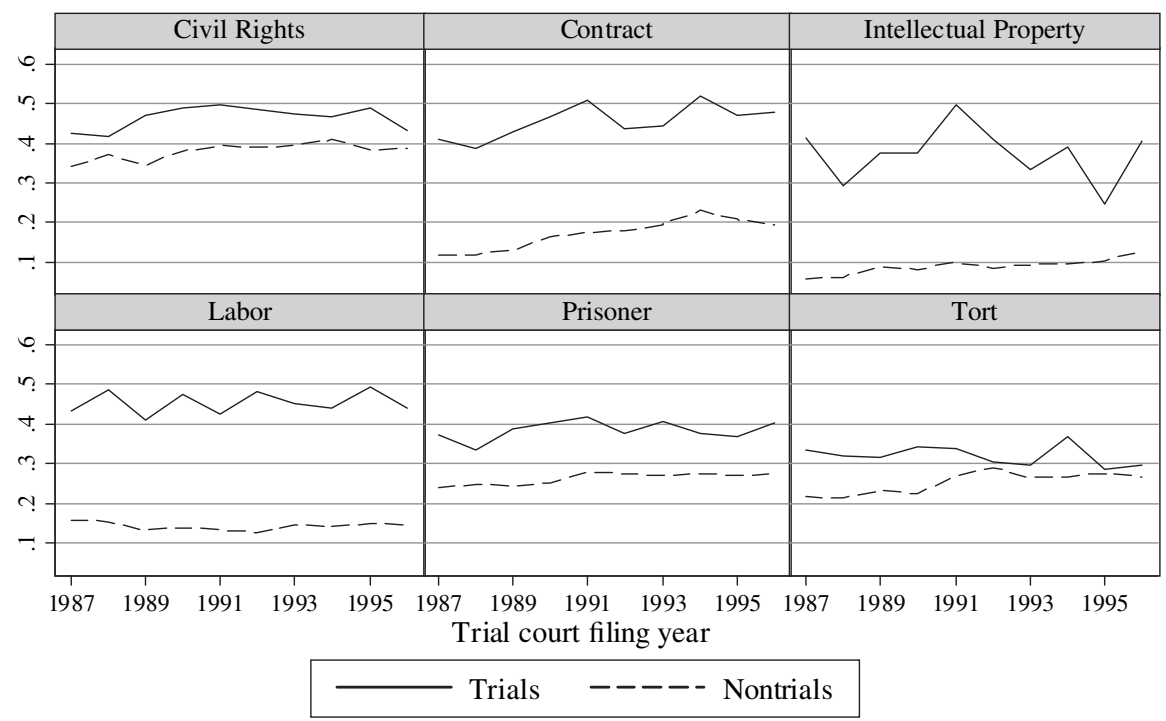

Note: Y-axis shows the proportion of district court filings appealed. Appeal rates are based on the number of district court filings and trials, and the number of appeals filed, regardless of whether the appeals were pursued to a conclusion on the merits. The convention used to match district court and appellate court cases is that followed in Table 1.

Source: Administrative Office of the U.S. Courts.

cases, with both rates at about 40 percent of district court filings. The differences in appeal rates are greatest in contract, intellectual property, and labor cases. Appeal rates in tried contract and labor cases have been around 50 percent.

The most discernable time trend is the convergence of appeal rates in tried and nontried tort cases after 1991. In the more recent years reported, tort-appeal rates have not been substantially different in tried and nontried cases. For both tried and nontried cases, appeal rates converge at just under 30 percent of district court filings. Other trends include increased appeal rates over time in nontried contract cases, in nontried intellectual property cases, and in nontried tort cases. These increasing rates contribute to Figure 1's indication that nontrial-appeal rates increased over time.

Figure 5 shows the rates at which filed cases were appealed to conclusion on the merits. The highest rates have been in civil rights, contract, and labor cases that reached trial. Civil rights and tort cases have the highest appeal-to-conclusion rates in nontried cases and intellectual property cases have by far the lowest rate in tried cases. 
Figure 5: Appeal rate to conclusion on the merits, by case category, district court filings, 1987-1995.

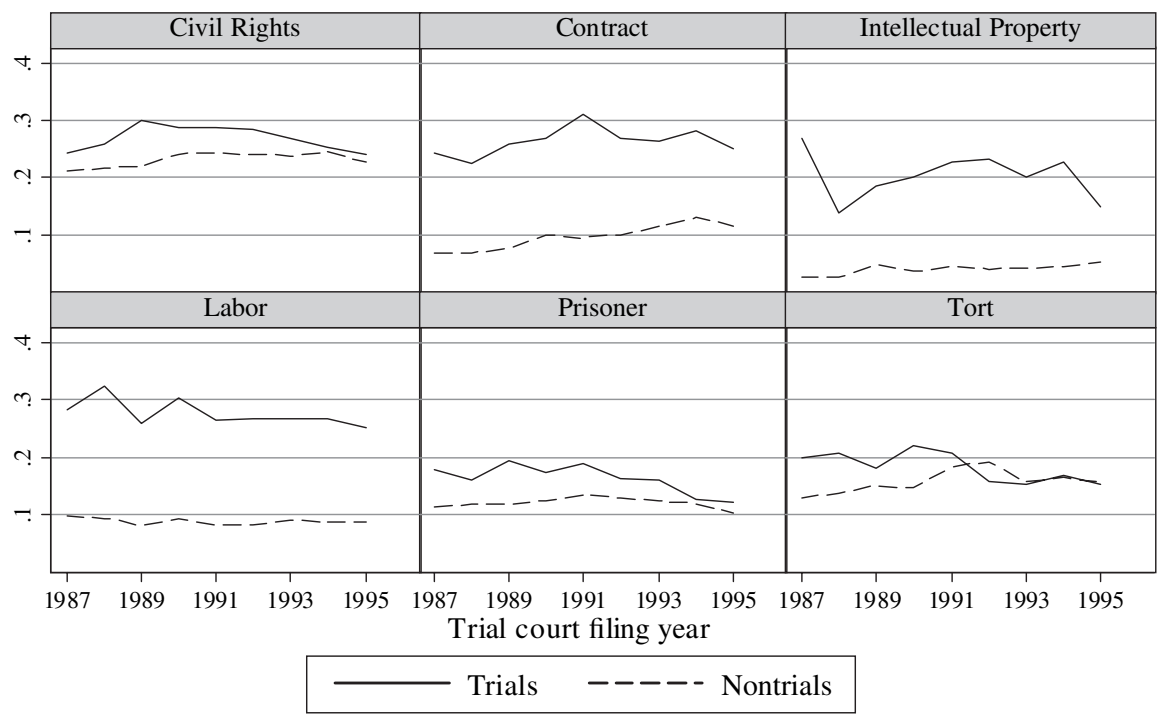

Note: Y-axis shows the proportion of district court filings appealed to conclusion. The number of appeals is limited to appeals that were pursued to a conclusion on the merits. The convention used to match district court and appellate court cases is that followed in Table 1.

SOURCE: Administrative Office of the U.S. Courts.

Some time trends emerge. Tort case appeal rates in tried and nontried cases have converged: they crossed after the 1991 filing year and remained in lockstep through 1995 filings. Civil rights and prisoner appeal-to-conclusion rates in tried and nontried cases also have converged over time. Civil rights cases, contract cases, intellectual property cases, and tort cases show an increase in appeal to conclusion over time in cases that did not reach district court trials. Labor, prisoner, and tort cases show declining rates of appeals to conclusion of trials.

Figure 6 shows the proportion of concluded appeals that are from cases tried in the district courts. The proportion declined over time in all six major case categories. The jagged appearance of the intellectual property part of the figure likely is attributable to the relatively small number of cases in that category (see the Appendix tables for aggregate numerical details). The other five categories show a nearmonotonic decline in the proportion of concluded appeals that are from trials. The vanishing trial at the district court level corresponds with a substantial decline in review of trials at the appellate court level. 
Figure 6: Proportion of concluded appeals that are from trials, by case category, 1987-1995.

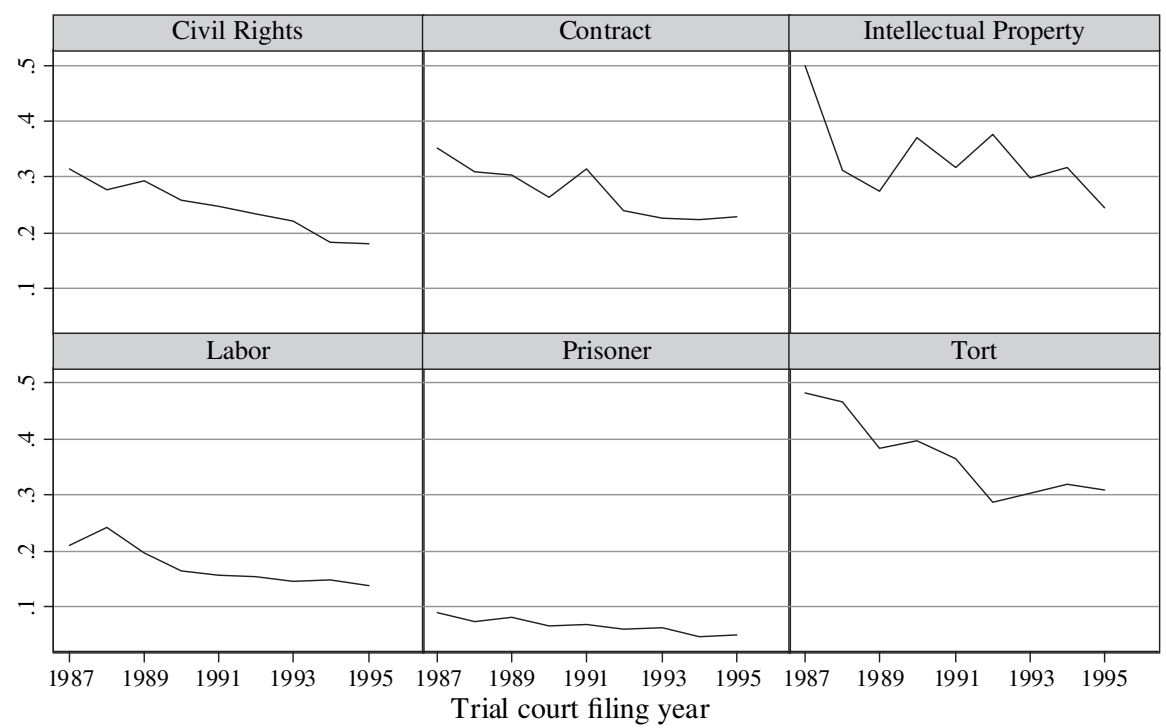

Note: Y-axis shows the proportion of concluded appeals that are from district court trials. The number of appeals used to calculate the proportion is limited to appeals that were pursued to a conclusion on the merits. The convention used to match district court and appellate court cases is that followed in Table 1.

SourcE: Administrative Office of the U.S. Courts.

\section{B. Time Trends by Case Category and Plaintiff-Defendant Status}

Table 3 suggests substantial differences in appeal rates by plaintiffs and defendants. This section explores time trends in appellate activity based on both trial and nontrial status and on plaintiff-defendant status.

For each of the six major case categories, Figure 7 shows the plaintiff and defendant appeal rates from district court losses at trial and in nontried cases. The highest appeal rates are from defendant trial losses, a characteristic that is consistent over the time period studied. The defendant appeal rate can exceed 60 percent in civil rights case trial losses. The lowest appeal rates tend to be from defendant nontrial losses. In prisoner cases, the plaintiff appeal rate from nontrial losses tends to be lowest. The low defendant appeal rate in nontrial losses may reflect the fact that some judgments for plaintiffs are the result of settlements, with little likelihood of appeal by a settling defendant.

In general, the time trends in Figure 7 are not striking. But the rates of defendant appeals from civil rights trials and contract trials increased by nontrivial 
Figure 7: Appeal rate, by case category and party, district court filings, 1987-1996.

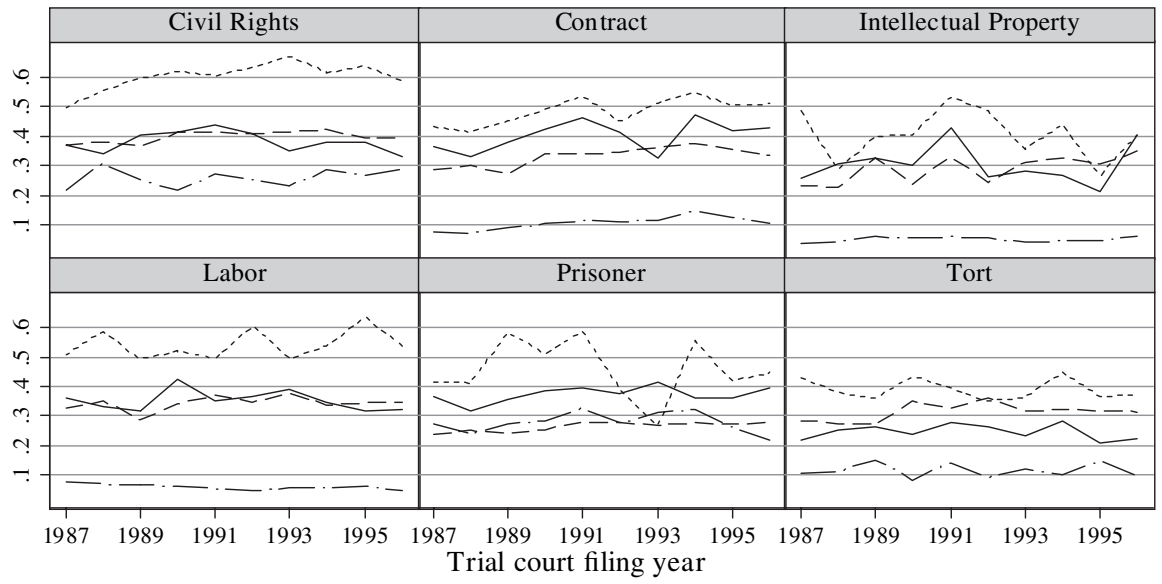

\begin{tabular}{|lll|}
\hline & P Appeals Trials & ----- P Appeals Nontrials \\
-........-. D Appeals Trials & D - - - D Appeals Nontrials
\end{tabular}

NoтE: Y-axis shows the proportion of district court filings appealed. Appeal rates are based on the number of district court filings and trials, and the number of appeals filed, regardless of whether the appeals were pursued to a conclusion on the merits. The convention used to match district court and appellate court cases is that followed in Table 1.

Source: Administrative Office of the U.S. Courts.

amounts. Plaintiff appeals in nontried cases are up modestly in civil rights, contract, prisoner, and tort cases, and up more substantially in intellectual property cases, though the pattern in intellectual property cases is volatile, which could be a result of relatively few cases per year.

Figure 8 explores the rates at which cases are appealed to a conclusion on the merits. The overall pattern is similar to that of appellate filings shown in Figure 7. As in the aggregate data that does not differentiate by case category, the rates of appealing to a conclusion are noticeably lower than the rates of filing an appeal. For example, the rate at which defendants pursue to conclusion appeals of civil rights case trial losses is less than 40 percent, compared to the over 60 percent rate at which such appeals are filed. Defendant appeals of tort trial losses drop from a filing rate of about 40 percent to an appeal-to-conclusion rate of about 20 percent.

The most striking decline is the rate of defendant appeals from trial outcomes in prisoner cases. Defendant appeal rates from trial losses also declined in labor and tort cases, but increased in contract cases. Plaintiff appeal-to-conclusion rates in nontried cases decreased or remained approximately level in all case categories. 
Figure 8: Appeal-to-conclusion rates, by case category and party, district court filings, 1987-1995.

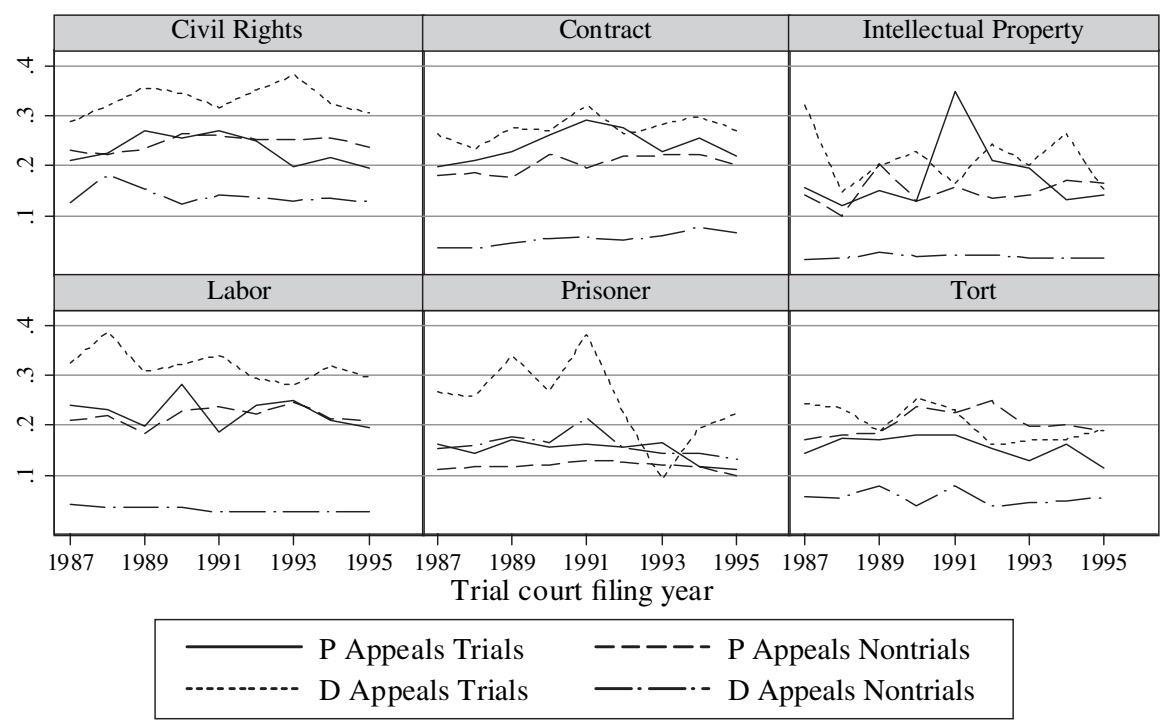

Note: Y-axis shows the proportion of district court filings appealed to conclusion. The number of appeals is limited to appeals that were pursued to a conclusion on the merits. The convention used to match district court and appellate court cases is that followed in Table 1.

SOURCE: Administrative Office of the U.S. Courts.

\section{EXPLORING REVERSAL-RATE PATTERNS}

A striking feature of Tables 1 and 2 is the asymmetrical pattern of reversals. Defendants succeed on appeal at a greater rate than plaintiffs and the pattern seems independent of the method of matching district court and appellate court cases. The Appendix tables indicate that this effect persists across almost all the major case categories.

This part explores what such asymmetry in reversal rates may signify. It first suggests an approach to what one might expect appellate reversal-rate patterns to look like and then tests those observations using observed appellate activity in one important class of federal civil cases, employment discrimination disputes. This approach draws on preliminary work in progress by Professor Henry Farber and me.

\section{A. What Shapes Observed Appellate-Reversal Patterns?}

What should one conclude from the asymmetrical pattern of plaintiff and defendant appellate success? One ought not simply accept these patterns at face value as evi- 
dence on which to base policy. ${ }^{11}$ Too much else is going on, including the trial court's behavior, the decision whether to appeal, posttrial and postappellate filing settlement behavior, and other factors to permit strong inferences based on raw appellate statistics. At a minimum, one would at least want to model the decision to appeal, as well as the appellate outcome, before reading much into the pattern of appellate outcomes. $^{12}$

Another approach to what to make of the asymmetrical pattern is to ask what reversal rates one might expect to observe. Developing a set of reasonable expectations is a less trivial task than one might initially assume because it depends on several assumptions about how trial courts and appellate courts behave. I do not produce here a formal model of appeal in the spirit of Steven Shavell's work. ${ }^{13}$ Rather, I preliminarily explore a set of assumptions helpful in assessing observed appellate outcomes. The approach is not intended to be exhaustive or conclusive-merely suggestive of the need for careful parsing of assumptions and data in assessing appellate outcomes. For example, I do not explore the extent to which variation in litigant costs or preferences might affect observed outcomes. ${ }^{14}$ Whatever the influence of these factors, assumptions about at least four important parameters seem necessary: rates of trial court success; rates of trial court error; rates of party appeals; and rates of appellate court error.

First, one needs to specify a trial-win rate because, as shown below, the trialwin rate substantially influences the appellate-win rates one might expect to observe. ${ }^{15}$ Second, one needs to estimate the trial court's rate of error. One can observe trial outcomes but it is less easy to know which outcomes to regard as mistakes likely to trigger an appeal and a reversal. Third, one needs to specify a rate of appeals. Appellate courts can affirm or reverse only cases that litigants bring before them. A 90 percent trial court error rate might generate a low appellate court reversal rate if erroneous cases tend not to be appealed. Fourth, one needs to specify a rate of disagreement between the appellate court and the trial court. Appellate courts are not perfect but, to justify their existence, the system must assume that

\footnotetext{
${ }^{11}$ See Steven Shavell, The Appeals Process as a Means of Error Correction, 24 J. Legal Stud. 379, 414 (1995) ("For a variety of reasons, however, statistics on reversal may actually tell us very little in themselves.").

${ }^{12}$ Clermont \& Eisenberg, Plaintiphobia, supra note 1.

${ }^{13}$ For other discussions of the appellate process, see authorities cited in Shavell, supra note 11, at 383 n.6.

${ }^{14}$ Id. at 392 (heterogeneity among litigants with respect to costs, risk aversion, or error perceptions means that litigant decisions about whether to bring appeals will depend on factors different from the actual occurrence of errors at trial).

${ }^{15}$ Table 5 and accompanying text.
} 
appellate courts have advantages over trial courts in reaching accurate outcomes. ${ }^{16}$ The list of assumptions is perhaps more lengthy than one would like but necessary.

\section{Trial Court Error Rates}

Assume that trial courts err in 10 percent of their cases. By err, I mean issue a ruling that an appellate court would justifiably point to as a basis for reversal. ${ }^{17}$ The assumed 10 percent error rate thus ignores immaterial errors, harmless errors, and errors insufficiently egregious to warrant appellate reversal. Ten percent is obviously an estimate but not a completely uninformed guess. We know that parties appeal to conclusion about 20 percent of tried cases and that about one-third of those appeals lead to reversals. ${ }^{18}$ This yields a preliminary trial court error rate of not less than about 7 percent. But of course some cases with trial court errors are not appealed and some appeals are dropped due to cost or settlement, so the 7 percent rate is probably closer to a floor than a ceiling. Ten percent likely is at the upper end of the trial court error rate but probably not off by more than a factor of two.

\section{Appeal Rates}

Given a trial court error rate, what is a likely appeal rate? It is sensible to assume two different rates of appeal; one for cases in which the trial court erred and a second rate for cases in which the trial court was correct. ${ }^{19}$ One expects the second rate to be substantially lower than the first but neither rate is precisely known. Parties do not appeal randomly but must be more likely to appeal mistakes than correct judgments. Based on real-world appeal rates, we assume an appeal rate of 20 percent in cases in which the trial court was correct. Parties evaluating their appellate prospects are thus assumed to correctly decide against appeal in 80 percent of correct trial court rulings. But, for a host of imaginable reasons-high stakes, low costs, or just plain error-they opt to appeal in 20 percent of cases with correct trial court rulings. For cases in which the trial court erred, we assume a 50 percent appeal rate. Parties are unlikely to perfectly identify trial court mistakes so only about 80 percent of mistakes might be appealed absent other factors. But the costs of appeal, the demoralizing effect of a trial loss, the need for closure, and other factors might lead parties

\footnotetext{
${ }^{16}$ Shavell, supra note 11 , at 386 .

${ }^{17}$ For discussion of the meaning of error, see id. at 413 .

${ }^{18}$ Table 1 . The appeal rate and reversal rate decline somewhat if one uses the stricter criteria for matching appellate court and district court data reported in Table 2.

${ }^{19}$ Shavell, supra note 11, at 384, 390 ("Accordingly, there may be separation of disappointed litigants, wherein those who are the victims of error find it worthwhile to bring appeals and those who are not do not find it worthwhile to bring appeals.").
} 
to appeal considerably less than 100 percent of the cases in which they correctly determine that an error occurred. So the 50 percent appeal rate allows well over half of truly mistaken cases to be appealed.

\section{Appellate Court Error}

Given trial court error and an appeal, what appellate reversal rates might be expected? Here again one should divide the cases into two groups. One expects appellate courts to reverse a higher rate of cases appealed that contain true error than of cases appealed that do not contain error. I assume that the appellate court will reverse 80 percent of the cases with true error and 20 percent of the cases without error. The appellate court thus gets matters overwhelmingly correct but introduces its own errors into the process. These instances of disagreement with the trial court might not be regarded as errors but could be cast as cases of legitimate appellate court-trial court disagreement.

Shifting from percentages to actual numbers of cases helps illustrate the numerical processes and the influence of the trial-win rate on appellate outcomes. Assume, for example, that the "true" plaintiff-win rate at trial in a class of cases should be 35 percent ${ }^{20}$ but that district courts err in 10 percent of the cases. Start with 1,000 trials. Based on our assumption, plaintiffs should win 350 trials. Due to 10 percent error, plaintiffs in fact win 315 of those trials and lose 35 . Defendants should win 650 trials. Due to 10 percent error, defendants win 585 of those trials and lose 65 .

As described above, the assumed likelihood of appeal is 50 percent when the district court errs and 20 percent when the district court was correct. Assume these appeal rates are the same for both plaintiffs and defendants. This leads to plaintiff appeals in 17.5 erroneous losses and 117 (20 percent of 585) accurate plaintiff losses, a total of 134.5 plaintiff appeals. The same assumptions lead to defendant appeals in 32.5 erroneous defendant losses and 63 (20 percent of 315) accurate defendant losses, a total of 95.5 defendant appeals.

Now apply assumptions about appellate court behavior to the 135 (rounded) plaintiff appeals and 96 (rounded) defendant appeals. The assumptions dictate that the appellate court will reverse 80 percent of the 17.5 erroneous plaintiff losses (14 cases) and will reverse 20 percent of the 117 accurate plaintiff losses (23.4 cases). Thus, plaintiff appeals will yield 37.4 reversals out of the total of 134.5 plaintiff appeals, a reversal rate of 27.8 percent. With respect to defendant appeals, the appellate court will reverse 80 percent of the 32.5 erroneous defendant losses (26 cases)

\footnotetext{
${ }^{20}$ Both theoretical considerations and empirical data suggest that trial-win rates can vary substantially. Steven Shavell, Any Frequency of Plaintiff Victory at Trial Is Possible, 25 J. Legal Stud. 493 (1996); Theodore Eisenberg, Testing the Selection Effect: A New Theoretical Framework with Empirical Tests, 19 J. Legal Stud. 337 (1990).
} 
Table 5: Hypothesized Appellate Reversal Rates as a Function of Trial-Win Rates

\begin{tabular}{lccc}
\hline $\begin{array}{l}\text { Objectively Correct } \\
\text { Plaintiff Trial Win Rate }\end{array}$ & $\begin{array}{c}\text { Reversal Rate in } \\
\text { Plaintiff Appeals }\end{array}$ & $\begin{array}{c}\text { Reversal Rate in } \\
\text { Defendant Appeals }\end{array}$ & $\begin{array}{c}\text { Plaintiff Minus } \\
\text { Defendant Difference }\end{array}$ \\
\hline 0.2 & 0.24 & 0.52 & -0.28 \\
0.25 & 0.25 & 0.47 & -0.22 \\
0.3 & 0.26 & 0.44 & -0.17 \\
0.35 & 0.28 & 0.40 & -0.13 \\
0.4 & 0.29 & 0.38 & -0.08 \\
0.45 & 0.31 & 0.35 & -0.04 \\
0.5 & 0.33 & 0.33 & 0.00 \\
0.55 & 0.35 & 0.31 & 0.04 \\
0.6 & 0.38 & 0.29 & 0.08 \\
0.65 & 0.4 & 0.28 & 0.13 \\
0.7 & 0.44 & 0.26 & 0.17 \\
0.75 & 0.47 & 0.25 & 0.22 \\
0.8 & 0.52 & 0.24 & 0.28
\end{tabular}

Note: The table shows the expected difference in plaintiff and defendant reversal rates (fourth column) based on presumed objective rates at which plaintiff should win at trial (first column). See text for assumptions generating the hypothetical reversal rates.

and 20 percent of the 63 appealed correct defendant losses (12.6 cases). Thus, defendant appeals will yield 38.6 reversals out of 95.5 appeals, a reversal rate of 40.6 percent.

Defendants fare noticeably better on appeal than plaintiffs, obtaining reversals in 40.6 percent of appealed cases, compared to plaintiffs obtaining reversals in 27.8 percent of appealed cases, a difference of 12.8 percent. Importantly, this difference is not a consequence of (1) appellate courts treating plaintiff appeals differently from defendant appeals, or (2) trial courts making mistakes at greater rates against plaintiffs or defendants. The appellate court reversed and affirmed cases at similar rates for both parties; the trial court made errors at the same rates for both parties. The asymmetrical appellate reversal rates on appeal flow from the assumed "correct" trial court win rates. The assumed trial court error rates and the assumed appeal rates influence the asymmetry's magnitude. But the asymmetry's existence stems from a trial court win rate that differs from 50 percent. The "haves" may come out ahead on appeal but their greater success rate may be completely attributable to their having come out ahead below.

Using the same assumptions about trial court error rates, appeal rates, and appellate court behavior, Table 5 shows the plaintiff appeals reversal rate, the defendant appeals reversal rate, and the difference (plaintiff reversal rate minus defendant reversal rate) for a series of assumed "true" plaintiff trial win rates, in addition to the 35 percent rate used for illustrative purposes.

The table indicates that, given the underlying assumptions, for any plaintiff trial win rate of less than 50 percent, the observed appellate court reversal rates will 
Table 6: Trial-Win Rates, Appeal Rates, Actual/Simulated Appellate Outcomes, Federal Employment Discrimination Cases, 1988-1995

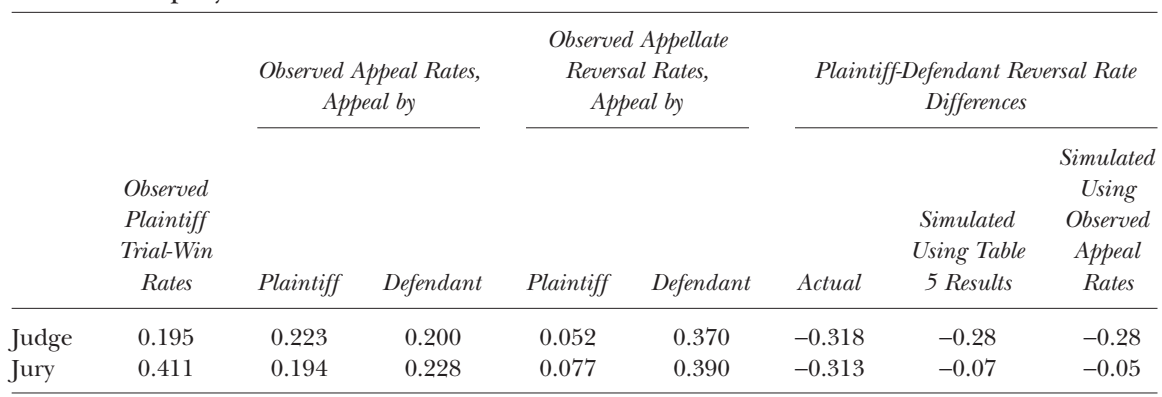

Note: The "Observed Plaintiff Trial-Win Rates" summarize the outcome of federal district court employment discrimination trials that ended in judgments for plaintiffs or defendants. The "Observed Appeal Rates" and "Observed Appellate Reversal Rates" are based on cases appealed to conclusion. These rates are based on the assumption that trial judgments for plaintiffs are appealed by defendants and trial judgments for defendants are appealed by plaintiffs. Thus, for example, the 0.223 appeal rate for plaintiffs in judge-tried cases indicates that plaintiffs appealed 22.3 percent of the trials they lost before judges. The 0.052 reversal rate in such appeals indicates that the appellate court reversed the trial court in 5.2 percent of the appeals pursued to conclusion by plaintiffs and affirmed in 94.8 percent of such appeals. The "Actual" difference in plaintiff-defendant reversal rates, reported in the sixth numerical column, is the difference between the observed reversal rates for plaintiffs and defendants. The first simulated reversal rate difference, reported in the seventh numerical column, is based on the assumptions discussed in text that generate the results in Table 5 . The second simulated reversal rate difference substitutes the actual observed appeal rates by plaintiffs and defendants in lieu of the appeal rates assumed in generating Table 5.

Source: Administrative Office of the U.S. Courts. District court and appellate court files are matched without filtering based on consolidation of appeals, docket numbers that reappear in the data sets, or other criteria, as in Table 1.

favor defendants. Correspondingly, for any plaintiff trial win rate of more than 50 percent, the observed appellate court reversal rates will favor plaintiffs.

\section{B. Analyzing the Reversal Rate in Employment Discrimination Cases}

So far, the analysis of reversal-rate asymmetry between plaintiff and defendant appeals is hypothetical but we now inject actual trial win rates, appeal rates, and appellate outcomes from an important class of cases, federal employment discrimination cases. The data are essentially the same as those analyzed in Parts I-III. The analysis uses the criteria for matching district court and appellate court cases, as reported in Table 1 . The data analyzed here cover cases matched from 1988 through 1995.

Table 6 combines actual employment discrimination case data (Administrative Office Case Category Code 442) ${ }^{21}$ with the simulation results described in Table 5. It shows that during the relevant time period, plaintiffs prevailed in 19.5 percent of

\footnotetext{
${ }^{21}$ See Civ. Stat. Reporting Guide, supra note 3.
} 
2,779 judge trials and 41.1 percent of 2,380 jury trials. Plaintiffs appealed to conclusion 22.3 percent of their judge-trial losses and defendants appealed to conclusion 20.0 percent of their judge-trial losses. Plaintiffs achieved reversal in 5.2 percent of their judge-trial appeals. Defendants achieved reversal in 37.0 percent of their judge-trial appeals. The 31.8 percent difference is reported in Table 6's sixth numerical column. The next column reports the estimated difference between plaintiff and defendant reversal rates based on Table 5's results and its underlying assumptions. Interpolation or exrapolation near Table 5 values for trial rates is applied where necessary.

For jury-tried cases, plaintiffs appealed to conclusion 19.4 percent of their jurytrial losses and defendants appealed to conclusion 22.8 percent of their jury-trial losses. Plaintiffs achieved reversal in 7.7 percent of their jury-trial appeals and defendants achieved reversal in 39.0 percent of their jury-trial appeals, yielding a difference of 31.3 percent. ${ }^{22}$ In the second alternative analysis, which seeks to exclude the murky plaintiff cases from the analysis, a different algorithm is used. To compute the plaintiff-appeal rate, I use a numerator equal to the number of appeals of cases with trial judgments entered for defendants (without addition of plaintiff appeals of plain-

\footnotetext{
${ }^{22}$ Table 6's analysis treats all appeals from judgments for plaintiffs as defendant appeals. Alternative analyses, not reported here, explore the sensitivity of results to how one treats cases ending with trial judgments for plaintiffs that show a plaintiff as the appellant in the appellate court data. See note 6 . One alternative analysis treats judgments for plaintiffs with plaintiffs as named appellants as plaintiff appeals and trial losses by plaintiffs. (For reasons discussed in note 6, this alternative excludes pre-1995 Fifth Circuit cases.) A second alternative treats judgments for plaintiffs with plaintiffs as appellants as ambiguous and seeks to eliminate their effect on computed results. Both alternative analyses are consistent with the results reported in Table 6.

In the first alternative analysis, the defendant appeal rate is reduced by some trials ending in judgment for plaintiffs being treated as plaintiff appeals. To compute the defendant-appeal rate, I use a numerator consisting of the number of appeals of cases with judgment for plaintiffs minus the number of such appeals that appear to be by plaintiffs. I use as the denominator the number of plaintiff trial wins minus the fraction of such wins estimated to be judgments for plaintiffs that may be judgments for defendants. That fraction is computed using the ratio of appeals by plaintiffs of judgments for plaintiffs divided by the sum of the appeals by plaintiffs of judgments for plaintiffs plus the number of plaintiff appeals of judgments for defendants. I then use the observed appellate court pattern of appeals by plaintiffs of judgments for plaintiffs to estimate the fraction of trial outcomes that are recorded as judgments for plaintiffs but are really judgments for defendants.

For purposes of computing the defendant-appeal rate, treating the murky plaintiff judgment cases as defendant wins (which defendants do not appeal) or as ambiguous cases to exclude from the sample (which defendants also do not appeal) yields the same defendant-appeal rate. The pool of defendant appeals in each case is reduced by the number of plaintiff appeals of plaintiff judgments and the pool of cases from which defendants might appeal is reduced in each case by the same fraction of nominal plaintiff trial wins.

The plaintiff-appeal rate varies depending on the alternative analysis used. In treating the murky plaintiffs judgment cases as defendant wins, I compute the plaintiff-appeal rate using a numerator equal to the number of appeals of cases with trial judgments for defendants plus the number of plaintiff appeals of cases showing trial judgments for plaintiffs. The denominator is the number of trials with judgments for defendants plus a fraction of the number of trials with judgments for plaintiffs. The last term is added because I treat a fraction of the nominal plaintiff trial wins a plaintiff trial losses.
} 
tiff judgments) and a denominator equal to the number of judgments for defendants (without addition of some judgments for plaintiffs that we treat as judgments for defendants).

Table 6 indicates that, using our assumptions, one might expect defendants to prevail on appeal (obtain reversals) in judge-tried cases 28 percent more than plaintiffs. In jury-tried cases, the defendant advantage is expected to be 7 percent or 5 percent, depending on which simulation is used. (These figures appear in the "Simulated" columns of Table 6 . The table's "Actual" column show that the actual defendant appellate advantage is larger than the simulations. In judge-tried cases, it is 31.8 percent and in jury-tried cases it is 31.3 percent.)

Which of our assumptions might be unsupported by actual practice in a way that leads to poorer-than-predicted plaintiff performance? Three major possibilities exist: one based on appeal rates, one based on trial court error rates, and one based on appellate court treatment.

First, assume the observed trial win rates are correct and that no asymmetry exists in trial court error as between plaintiffs and defendants. Since appellate outcomes are known and not hypothesized, the strongest candidate for explaining the disparity between actual and simulated plaintiff-defendant appellate differences then becomes the appeal rate. Differential appeal rates by the parties could theoretically lead to a set of appeals that lead to the observed differences. For example, if plaintiffs appeal a higher proportion of their "correct" trial losses than defendants, the reversal rates for plaintiff appeals will be driven down relative to the reversal rate for defendant appeals. The difference between the actual and simulated plaintiffdefendant appellate outcome differences could be attributable to such different appeal rates.

However, neither the appeal rates from judge trials nor the appeal rates from jury trials offer much explanatory hope here. In judge-tried cases, Table 6 shows that the parties appeal to conclusion trial losses at essentially the same rate-about 20 percent of trial losses. In jury-tried cases, defendants appeal at a higher rate than plaintiffs. A higher defendant-appeal rate should reduce, not increase, the defendants' appellate advantage. So the actual-simulated difference is unlikely to be a consequence of appeal rates.

Second, the assumption of symmetric trial error may be erroneous. For the symmetric-error assumption to be erroneous in a way that explains the data, the asymmetry must be in a specific direction. Trial courts must err in favor of plaintiffs more than in favor of defendants, thereby leading to greater-than-expected defendant reversals on appeal. Whether this greater error is objectively true error, or simply error in the eyes of the appellate court, the appellate courts regard plaintiffs less favorably than do trial courts.

Third, assume trial errors are symmetric and appeal rates, as observed, are nearly equal. That leaves appellate court treatment as an explanation of greater defendant success. Appellate courts could be biased against plaintiffs or might inter- 
pret the law in a more pro-defendant manner. Both these explanations also are consistent with appellate courts viewing plaintiffs less favorably than do trial courts.

The data thus suggest, subject to the assumptions stated, that there is an appellate court effect independent of trial win rates and appeal rates that depresses plaintiff success on appeal in employment discrimination cases.

\section{CONCLUSION}

Computing accurate appeal rates requires data about the mass of cases that are not appealed. This article attempts to trace the universe of district court filings to conclusion, whether the conclusion be at the district court level or at the appellate court level. About 20 percent of cases with definitive trial court judgments generate appeals, with tried cases appealed at about twice the rate of nontried cases. Over time, tried cases appear to be a decreasing proportion of appellate outcomes. Substantial variation exists in appeal rates and outcomes across major case categories and by party status as plaintiff or defendant. In all major case categories, defendants succeed on appeal more than plaintiffs. Some of this difference likely is attributable to the pool of cases chosen for appeal, but some of the difference also appears to be attributable, at least in employment discrimination cases, to appellate court effects. 


\section{APPENDIX}

For the following six category-specific tables, appeal rates include district court cases filed from 1987 through 1996. Appeal-to-conclusion rates and appellate outcomes include district court cases filed from 1987 through 1995. District court and appellate court files are matched without filtering based on consolidation of appeals, docket numbers that reappear in the data sets, or other criteria.

Table A1: Appeal Rates and Appellate Outcomes, Federal Filings, 1987-1996, Stated Separately for Plaintiffs and Defendants (Contract)

\begin{tabular}{|c|c|c|c|c|c|c|}
\hline & $\begin{array}{l}\text { Number of } \\
\text { Judgments, } \\
1987-1996\end{array}$ & $\begin{array}{l}\text { Number of } \\
\text { Judgments, } \\
\text { 1987-1995 }\end{array}$ & $\begin{array}{c}\text { Appealed, } \\
1987-1996\end{array}$ & $\begin{array}{l}\text { Appealed to } \\
\text { Conclusion, } \\
1987-1995\end{array}$ & Affirmed & Reversed \\
\hline \multicolumn{7}{|c|}{ A. Judgments for Plaintiffs } \\
\hline All cases & 64,145 & 60,087 & $13.9 \%$ & $7.4 \%$ & $5.0 \%$ & $2.4 \%$ \\
\hline Trials & 6,781 & 6,316 & $47.6 \%$ & $27.2 \%$ & $16.9 \%$ & $10.3 \%$ \\
\hline Judge trials & 3,550 & 3,297 & $44.3 \%$ & $24.6 \%$ & $16.9 \%$ & $7.8 \%$ \\
\hline Jury trials & 3,231 & 3,019 & $51.1 \%$ & $30.1 \%$ & $17.0 \%$ & $13.1 \%$ \\
\hline All nontrials & 57,364 & 53,771 & $9.9 \%$ & $5.1 \%$ & $3.6 \%$ & $1.5 \%$ \\
\hline \multicolumn{7}{|c|}{ B. Judgments for Defendants } \\
\hline All cases & 26,176 & 23,686 & $34.1 \%$ & $20.8 \%$ & $15.9 \%$ & $5.0 \%$ \\
\hline Trials & 3,952 & 3,665 & $39.9 \%$ & $24.0 \%$ & $17.7 \%$ & $6.3 \%$ \\
\hline Judge trials & 1,974 & 1,832 & $39.7 \%$ & $24.7 \%$ & $17.7 \%$ & $6.9 \%$ \\
\hline Jury trials & 1,978 & 1,833 & $40.1 \%$ & $23.2 \%$ & $17.7 \%$ & $5.6 \%$ \\
\hline All nontrials & 22,224 & 20,021 & $33.0 \%$ & $20.3 \%$ & $15.5 \%$ & $4.7 \%$ \\
\hline
\end{tabular}

Table A2: Appeal Rates and Appellate Outcomes, Federal Filings, 1987-1996, Stated Separately for Plaintiffs and Defendants (Tort)

\begin{tabular}{lrrrrrr}
\hline & $\begin{array}{c}\text { Number of } \\
\text { Judgments, } \\
1987-1996\end{array}$ & $\begin{array}{c}\text { Number of } \\
\text { Judgments, } \\
1987-1995\end{array}$ & $\begin{array}{c}\text { Appealed, } \\
1987-1996\end{array}$ & $\begin{array}{c}\text { Appealed to } \\
\text { Conclusion, } \\
1987-1995\end{array}$ & Affirmed & Reversed \\
\hline A. Judgments for Plaintiffs & & & & & & \\
All cases & 19,624 & 18,215 & $23.9 \%$ & $12.5 \%$ & $7.1 \%$ & $5.4 \%$ \\
Trials & 8,879 & 8,158 & $39.3 \%$ & $21.0 \%$ & $11.2 \%$ & $9.8 \%$ \\
$\quad$ Judge trials & 2,599 & 2,394 & $41.4 \%$ & $19.7 \%$ & $10.8 \%$ & $8.9 \%$ \\
$\quad$ Jury trials & 6,280 & 1,245 & $38.3 \%$ & $21.6 \%$ & $11.4 \%$ & $10.2 \%$ \\
All nontrials & 10,745 & 10,057 & $11.2 \%$ & $5.6 \%$ & $3.7 \%$ & $1.9 \%$ \\
B. Judgments for Defendants & & & & & $19 \%$ & $3.9 \%$ \\
All cases & 32,210 & 29,002 & $29.6 \%$ & $19 \%$ & $15.3 \%$ & $2.5 \%$ \\
Trials & 8,351 & 7,664 & $24.6 \%$ & $15.8 \%$ & $13.2 \%$ & $3.2 \%$ \\
$\quad$ Judge trials & 2,126 & 1,981 & $28.2 \%$ & $19.1 \%$ & $15.9 \%$ & $2.3 \%$ \\
Jury trials & 6,225 & 5,683 & $23.4 \%$ & $14.6 \%$ & $12.3 \%$ & $4.4 \%$ \\
All nontrials & 23,859 & 21,338 & $31.3 \%$ & $20.4 \%$ & $16.1 \%$ & \\
\hline
\end{tabular}


Table A3: Appeal Rates and Appellate Outcomes, Federal Filings, 1987-1996, Stated Separately for Plaintiffs and Defendants (Civil Rights)

\begin{tabular}{|c|c|c|c|c|c|c|}
\hline & $\begin{array}{l}\text { Number of } \\
\text { Judgments, } \\
\text { 1987-1996 }\end{array}$ & $\begin{array}{l}\text { Number of } \\
\text { Judgments, } \\
\text { 1987-1995 }\end{array}$ & $\begin{array}{c}\text { Appealed, } \\
1987-1996\end{array}$ & $\begin{array}{l}\text { Appealed to } \\
\text { Conclusion, } \\
1987-1995\end{array}$ & Affirmed & Reversed \\
\hline \multicolumn{7}{|c|}{ A. Judgments for Plaintiffs } \\
\hline All cases & 13,992 & 12,581 & $41.1 \%$ & $22.3 \%$ & $11.6 \%$ & $10.7 \%$ \\
\hline Trials & 6,164 & 5,483 & $60.4 \%$ & $33.0 \%$ & $16.4 \%$ & $16.6 \%$ \\
\hline Judge trials & 1,734 & 1,618 & $53.3 \%$ & $30.2 \%$ & $14.4 \%$ & $15.8 \%$ \\
\hline Jury trials & 4,430 & 3,865 & $63.1 \%$ & $34.2 \%$ & $17.3 \%$ & $16.9 \%$ \\
\hline All nontrials & 7,828 & 7,098 & $25.9 \%$ & $14.0 \%$ & $7.9 \%$ & $6.1 \%$ \\
\hline \multicolumn{7}{|c|}{ B. Judgments for Defendants } \\
\hline All cases & 67,823 & 57,669 & $39.7 \%$ & $24.4 \%$ & $20.6 \%$ & $3.8 \%$ \\
\hline Trials & 10,485 & 9,386 & $38.1 \%$ & $23.1 \%$ & $19.8 \%$ & $3.3 \%$ \\
\hline Judge trials & 4,235 & 3,999 & $41.0 \%$ & $26.0 \%$ & $23.0 \%$ & $3.0 \%$ \\
\hline Jury trials & 6,250 & 5,387 & $36.1 \%$ & $20.9 \%$ & $17.4 \%$ & $3.5 \%$ \\
\hline All nontrials & 57,338 & 48,283 & $40.0 \%$ & $24.6 \%$ & $20.7 \%$ & $3.9 \%$ \\
\hline
\end{tabular}

Table A4: Appeal Rates and Appellate Outcomes, Federal Filings, 1987-1996, Stated Separately for Plaintiffs and Defendants (Prisoner)

\begin{tabular}{lrrrrrr}
\hline & $\begin{array}{c}\text { Number of } \\
\text { Judgments, } \\
1987-1996\end{array}$ & $\begin{array}{c}\text { Number of } \\
\text { Judgments, } \\
1987-1995\end{array}$ & $\begin{array}{c}\text { Appealed, } \\
1987-1996\end{array}$ & $\begin{array}{c}\text { Appealed to } \\
\text { Conclusion, } \\
1987-1995\end{array}$ & Affirmed & Reversed \\
\hline A. Judgments for Plaintiffs & & & & & & \\
All cases & 7,791 & 6,653 & $29.8 \%$ & $17.5 \%$ & $11.7 \%$ & $5.8 \%$ \\
Trials & 1,001 & 934 & $46.3 \%$ & $26.0 \%$ & $15.3 \%$ & $10.7 \%$ \\
$\quad$ Judge trials & 604 & 573 & $41.7 \%$ & $27.2 \%$ & $14.8 \%$ & $12.4 \%$ \\
$\quad$ Jury trials & 397 & 361 & $53.2 \%$ & $24.1 \%$ & $16.1 \%$ & $8.0 \%$ \\
All nontrials & 6,790 & 5,719 & $27.4 \%$ & $16.1 \%$ & $11.2 \%$ & $5.0 \%$ \\
B. Judgments for Defendants & & & & & $10 \%$ & $1.4 \%$ \\
All cases & 182,312 & 162,263 & $26.9 \%$ & $12.0 \%$ & $10.6 \%$ & $1.4 \%$ \\
Trials & 7,961 & 7,276 & $37.5 \%$ & $15.0 \%$ & $13.6 \%$ & $1.3 \%$ \\
$\quad$ Judge trials & 5,048 & 4,662 & $31.6 \%$ & $14.8 \%$ & $13.6 \%$ & $1.6 \%$ \\
$\quad$ Jury trials & 2,913 & 2,614 & $47.6 \%$ & $15.2 \%$ & $13.6 \%$ & $1.4 \%$ \\
All nontrials & 174,351 & 154,987 & $26.4 \%$ & $11.9 \%$ & $10.4 \%$ & \\
\hline
\end{tabular}


Table A5: Appeal Rates and Appellate Outcomes, Federal Filings, 1987-1996, Stated Separately for Plaintiffs and Defendants (Labor)

\begin{tabular}{|c|c|c|c|c|c|c|}
\hline & $\begin{array}{l}\text { Number of } \\
\text { Judgments, } \\
1987-1996\end{array}$ & $\begin{array}{l}\text { Number of } \\
\text { Judgments, } \\
1987-1995\end{array}$ & $\begin{array}{c}\text { Appealed, } \\
1987-1996\end{array}$ & $\begin{array}{l}\text { Appealed to } \\
\text { Conclusion, } \\
1987-1995\end{array}$ & Affirmed & Reversed \\
\hline \multicolumn{7}{|c|}{ A. Judgments for Plaintiffs } \\
\hline All cases & 32,513 & 29,540 & $8.0 \%$ & $4.6 \%$ & $2.5 \%$ & $2.1 \%$ \\
\hline Trials & 1,526 & 1,407 & $54.2 \%$ & $32.2 \%$ & $17.3 \%$ & $14.9 \%$ \\
\hline Judge trials & 1,029 & 958 & $51.0 \%$ & $29.7 \%$ & $14.8 \%$ & $12.4 \%$ \\
\hline Jury trials & 497 & 449 & $60.8 \%$ & $37.6 \%$ & $16.1 \%$ & $8.0 \%$ \\
\hline All nontrials & 30,987 & 28,133 & $5.8 \%$ & $3.2 \%$ & $1.8 \%$ & $1.5 \%$ \\
\hline \multicolumn{7}{|c|}{ B. Judgments for Defendants } \\
\hline All cases & 14,666 & 13,085 & $34.4 \%$ & $22.1 \%$ & $16.9 \%$ & $5.2 \%$ \\
\hline Trials & 1,341 & 1,242 & $35.3 \%$ & $22.6 \%$ & $16.9 \%$ & $5.7 \%$ \\
\hline Judge trials & 960 & 895 & $35.0 \%$ & $23.0 \%$ & $17.3 \%$ & $5.7 \%$ \\
\hline Jury trials & 381 & 347 & $36.0 \%$ & $21.6 \%$ & $15.9 \%$ & $5.8 \%$ \\
\hline All nontrials & 13,325 & 11,843 & $34.3 \%$ & $22.1 \%$ & $16.9 \%$ & $5.1 \%$ \\
\hline
\end{tabular}

Table A6: Appeal Rates and Appellate Outcomes, Federal Filings, 1987-1996, Stated Separately for Plaintiffs and Defendants (Intellectual Property)

\begin{tabular}{lrrrrrr}
\hline & $\begin{array}{c}\text { Number of } \\
\text { Judgments, } \\
1987-1996\end{array}$ & $\begin{array}{c}\text { Number of } \\
\text { Judgments, } \\
1987-1995\end{array}$ & $\begin{array}{c}\text { Appealed, } \\
1987-1996\end{array}$ & $\begin{array}{c}\text { Appealed to } \\
\text { Conclusion, } \\
1987-1995\end{array}$ & Affirmed & Reversed \\
\hline A. Judgments for Plaintiffs & & & & & & \\
All cases & 14,374 & 13,068 & $7.6 \%$ & $3.4 \%$ & $2.1 \%$ & $1.3 \%$ \\
Trials & 1,080 & 962 & $40.6 \%$ & $21.5 \%$ & $13.6 \%$ & $7.9 \%$ \\
$\quad$ Judge trials & 575 & 523 & $42.8 \%$ & $25.4 \%$ & $16.8 \%$ & $8.6 \%$ \\
$\quad$ Jury trials & 505 & 439 & $38.0 \%$ & $16.9 \%$ & $9.8 \%$ & $7.1 \%$ \\
All nontrials & 13,294 & 12,106 & $4.9 \%$ & $1.9 \%$ & $1.2 \%$ & $0.7 \%$ \\
B. Judgments for Defendants & & & & & $15 \%$ & \\
All cases & 3,142 & 2,718 & $29.7 \%$ & $15.5 \%$ & $10.2 \%$ & $5.3 \%$ \\
Trials & 498 & 439 & $30.5 \%$ & $17.8 \%$ & $11.6 \%$ & $6.2 \%$ \\
$\quad$ Judge trials & 299 & 264 & $32.8 \%$ & $20.5 \%$ & $15.2 \%$ & $5.3 \%$ \\
$\quad$ Jury trials & 199 & 175 & $27.1 \%$ & $13.7 \%$ & $6.3 \%$ & $7.4 \%$ \\
All nontrials & 2,644 & 2,279 & $29.6 \%$ & $15.1 \%$ & $9.9 \%$ & $5.1 \%$ \\
\hline
\end{tabular}

This information or any portion thereof may not be copied or disseminated in any form or by any means or downloaded or stored in an electronic database or retrieval system without the express written consent of the American Bar Association. 